\title{
PENGARUH PENERAPAN ALAT PERMAINAN EDUKATIF (APE) TERHADAP PENINGKATAN KEPERCAYAAN DIRI ANAK USIA 3-5 TAHUN DI KELOMPOK BERMAIN AISYIYAH 14 PABEAN CANTIAN KOTA SURABAYA
}

\author{
Novira Dwi Prapti, Wesiana Heris Santy \\ Fakultas Keperawatan dan Kebidanan \\ Universitas Nahdlatul Ulama Surabaya, Jalan SMEA No. 57 Surabaya \\ wesiana@unusa.ac.id
}

\begin{abstract}
Abstrak
Kepercayaan diri anak usia usia 3-5 tahun yang masih rendah menyebabkan anak sulit untuk berpisah dengan orang tua, tidak berani mengemukakan pendapat meskipun hal ini sesuai dengan tahap perkembangnnya, tetapi jika tidak distimulasi akan berdampak pada kepercayaan diri di masa depan. Tujuan penelitian menganalisis Efektifitas Penerapan Alat Permainan Edukatif (APE) terhadap peningkatan kepercayaan diri anak usia 3-5 tahun. Desain penelitian pre eksperiment dengan jenis one group pretest-posttest design. Populasi anak usia 3-5 tahun sebesar 33 anak, sampel 30. Tekhnik simple random sampling. Analisis data adalah Wilcoxon Sign Test. Variabel independent adalah penerapan APE dan variabel dependent adalah kepercayaan diri. Data dikumpulkan menggunakan lembar observasi dilanjutkan analisis dengan uji Wilcoxon dimana nilai $\alpha=0,05$. Hasil penelitian sebelum penerapan APE menunjukkan sebagian besar (70\%) mempunyai kepercayaan diri rendah dan hasil setelah dilakukan penerapan APE sebagian besar $(63,33 \%)$ mempunyai kepercayaan diri tinggi. Hasil uji analisis didapatkan nilai $\rho=0,000<\alpha=0,05$ maka Ho ditolak artinya APE efektif terhadap peningkatan kepercayaan diri anak usia 3-5 tahun di KB Aisyiyah 14 Pabean Cantian Kota Surabaya. Simpulan penelitian adalah sebagian besar anak memiliki kepercayaan diri tinggi sesudah diberikan penerapan APE. Saran terhadap profesi keperawatan penerapan APE dapat menjadi salah satu asuhan keperawatan untuk mengembangkan kepercayaan diri.
\end{abstract}

\begin{abstract}
Children who are 3-5 years in accordance with their development still have low self-confidence marked by their difficulty to separate with their parents and they are not brave to express an opinion. The purpose of the study is to analyze the effective of the application of Educational Game Tools (EGT) to the improvement of 3-5 year children self-confidence. The research design used pre experiment with one group pretest-posttest design. The population was 3-5 year children as 33 people, sample was 30 people. It used probability sampling with simple random sampling technique. Data analysis used Wilcoxon Sign Test statistical test. Independent variable was APE application and dependent variable was self-confidence. Data collection used observation sheet and analyzed by Wilcoxon test with $\alpha=0,05$. Pre-test result showed that most (70\%) had low self-confidence and posttest most $(63.33 \%)$ had high confidence. The result of the analysis test showed that $\rho=0,000<\alpha=$ 0,05 then Ho was rejected, it means EGT application effective to the increase of the 3-5 year children self-confidence in Aisyiyah playgroup14 Pabean Cantian Surabaya. The conclusion of this study is most children have high confidence after the implementation of EGT. It is suggested to the nursing profession that EGT implementation can be one of nursing care to develop self-confidence.
\end{abstract}

Keywords: Educational Game Tools, Self-Confidence.

\section{PENDAHULUAN}

Anak usia 3-5 tahun seharusnya mempunyai aspek perkembangan sosial yaitu kepercayaan diri. Kepercayaan diri merupakan aspek paling penting dalam kepribadian sesorang, tanpa ada rasa 
kepercayaan diri maka akan banyak menimbulkan masalah pada diri seseorang jika tidak dibina sejak kecil. Kepercayaan anak pada usia tersebut ditandai dengan anak berani untuk tampil di depan, tidak grogi, mempunyai pribadi yang positif, tidak malu-malu, mampu bersama dengan temannya dan anak terlihat gembira (Rahayu, 2013).

Dunia anak tidak bisa dipisahkan dengan dunia bermain. Keduanya bersifat universal pada semua bangsa dan kultur. Diharapkan dengan bermain, anak mendapatkan stimulasi yang cukup agar dapat berkembang secara optimal. Bermain merupakan media bagi anak untuk dapat berkembang sesuai dengan aspek-aspek perkembangan anak (Susilaningrum, 2013).

Alat permainan edukatif adalah segala macam sarana yang bisa merangsang aktivitas sehingga membuat senang dan sebagai media anak untuk meningkatkan dan mengembangkan kepribadiannya. (Adriana, 2013).

Prinsip dasar alat permainan edukatif adalah dapat meningkatkan dan mengembangkan kemampuan psikomotorik anak, sosial-emosional (seperti mempertajam perasaan, membentuk moralitas, spiritualitas dan meningkatkan kepercayaan diri (Adriana, 2013).
Percaya diri (Self confidence) adalah individu yang memiliki kemampuan untuk memahami dan meyakini seluruh potensi yang ada pada dirinya agar dapat menyesuaikan diri dengan lingkungan sosialnya. Anak yang mampu untuk meyakini potensi dirinya biasanya akan mempunyai inisiatif, optimis dan aktif (Dariyo, 2011).

Anak pra-sekolah memasuki tahap psikososial pertama dan kepercayaan diri haruslah dimiliki, tidak ada rasa takut atau kecemasan dalam masa depan. Anak yang memiliki keseimbangan tingkah laku, emosi, toleransi dan memiliki spiritualitas dalam dirinya sehingga anak akan menjadi sukses.

Pada masa usia pra sekolah khususnya usia 3-5 tahun, otak akan tumbuh secara cepat dengan memproduksi jutaan sel, koneksi atau sinaps diantara sel-sel tersebut, oleh sebab itu diperlukan berbagai tindakan untuk mengoptimalkan tumbuh kembang anak. Kemudian pada aspek kepribadian dan tingkah laku sosialnya berkembang melalui bermain dan selanjutnya akan terus berkembang jika anak mendapatkan perawatan yang benar sehingga menghasilkan perkembangan anak yang sehat, khususnya interaksi sosial anak (Rahayu, 2013).

Menurut Lautser (dalam Ghufron dan Risnawati 2012: 35) orang yang 
mempunyai rasa percaya diri yang tinggi pada umumnya mudah bergaul secara fleksibel, mempunyai toleransi yang cukup baik, bersikap positif, dan tidak mudah terpengaruh orang lain dalam bertindak serta mampu menentukan langkah-langkah dalam menyelesaikan suatu masalah. Tipetipe orang yang mempunyai rasa percaya diri tinggi akan terlihat lebih tenang, tidak merasa takut, dan mampu memperlihatkan kepercayaan dirinya setiap saat. Ciri-ciri anak yang memiliki rasa percaya diri untuk usia 3-5 tahun yaitu: berani tampil kedepan, berani mengungkapkan pendapat, tidak grogi dengan lingkungannya, mampu bekerja sama dengan temannya, mudah beradaptasi pada lingkungan yang baru, mampu melakukan aktivitasnya dengan bebas dan gembira.

Menurut Frobel (dalam Rahayu, 2013) mengemukakan bahwa pengenalan diperoleh melalui pengalaman anak dalam bermain. Melalui kegiatan bermain, anak dapat merasakan kebebasan untuk mengenal sesuatu melalui pengamatannya sebagai pengalaman. Salah satu terapi bermain yang dapat mengoptimalkan perkembangan kepercayaan diri anak salah satunya dengan penerapan alat permainan edukatif (APE).

Alat permainan edukatif (APE) adalah segala sesuatu yang dapat dipergunakan sebagai sarana atau alat permainan yang mengandung nilai pendidikan dan dapat mengembangkan seluruh aspek kemampuan anak. Aspek kepribadian anak salah satunya adalah kepercayaan diri. Alat permainan edukatif (APE) bisa meningkatkan kepercayaan diri anak (Adriana, 2013).

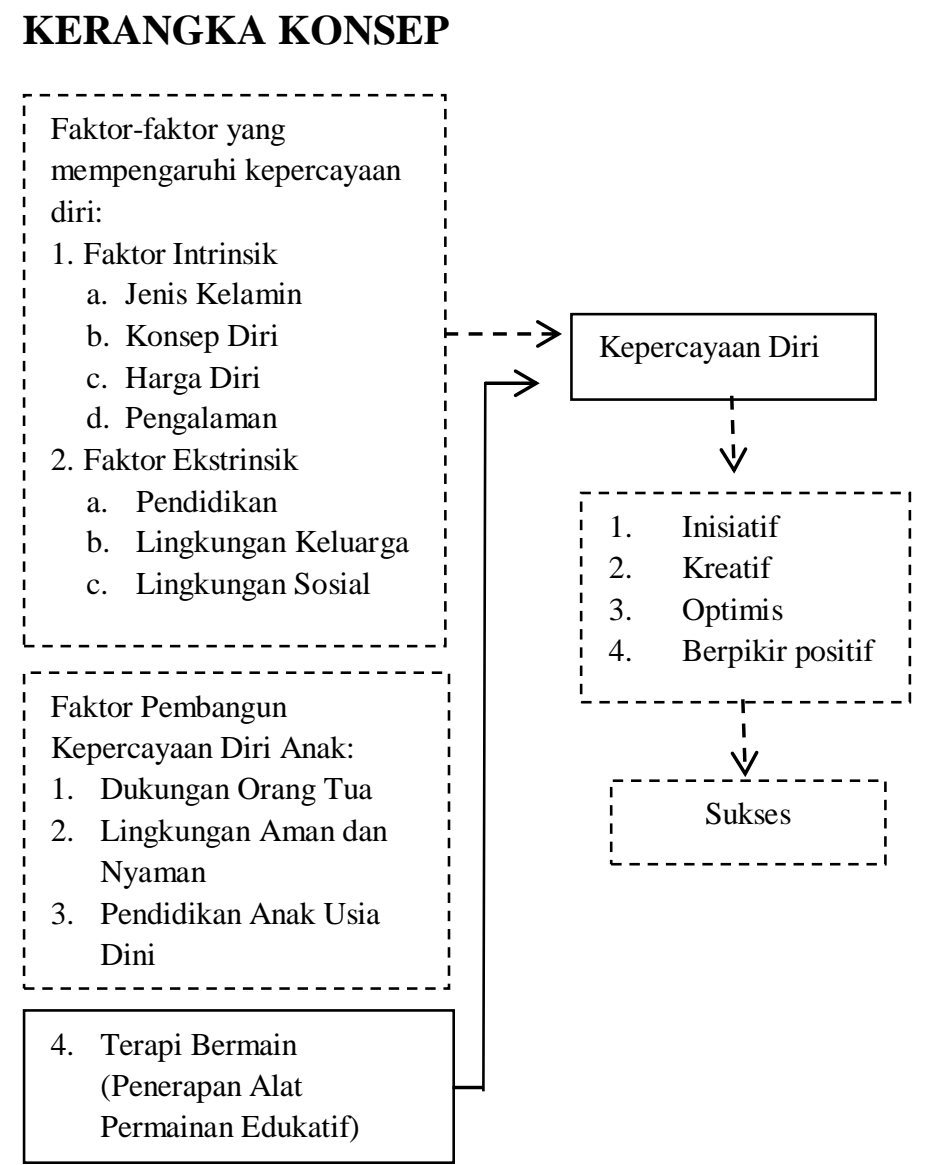

\section{METODE PENELITIAN}

Jenis penelitian yang digunakan adalah jenis penelitian experimental yaitu penelitian yang penelitiannya memberikan suatu perlakuan, treatment atau eksperimen dengan menggunakan bentuk rancangan Pre Eksperimental dengan 
desain One Group Pretes-Postest. Populasi dalam penelitian ini yaitu 33 anak, sampel yang digunakan dalam penelitian ini adalah menggunakan rumus:

$$
\begin{aligned}
n & =\frac{N}{1+N(d)^{2}} \\
n & =\frac{33}{1+33(0,0025)} \\
n & =\frac{33}{1+0.0825} \\
n & =\frac{33}{1,0825} \\
n & =30
\end{aligned}
$$

Teknik pengambilan sampel pada penelitian ini menggunakan Probability Sampling dengan menggunakan Simple Random Sampling.

Instrumen penelitian ini menggunakan lembar observasi dengan uji korelasi Wilcoxon Signt Rank Test dengan tingkat kemaknaan $\alpha=0,05$, apabila $<\alpha$ maka Ho ditolak berarti ada pengaruh.

Tahap Pengolahan Data:

a. Editing

Proses editing kegiatan untuk pengecekan dan perbaikan lembar observasi.

b. Coding

Koding adalah mengubah data berbentuk kalimat atau huruf menjadi data angka atau bilangan.

c. Processing

Setelah semua isi lembar observasi penuh, sudah melewati sistem coding maka langkah selanjutnya adalah memproses data agar dapat dianalisis.

\section{d. Cleaning}

Cleaning (pembersihan data) merupakan kegiatan pengecekan kembali data yang sudah di entry apakah ada kesalahan atau tidak.

e. Entry Data

Semua jawaban yang telah diberi kode kategori kemudian dimasukkan ke dalam tabel dengan cara menghitung frekuensi data.

f. Tabulasi

Dalam tabulasi data meliputi pemberian skor terhadap item-item yang perlu diberi skor.

\section{HASIL PENELITIAN}

Tabel 1 Distibusi frekuensi berdasarkan jenis kelamin anak di KB Aisyiyah 14 Pabean Cantian Kota Surabaya 2017

\begin{tabular}{cccc}
\hline No & $\begin{array}{c}\text { Jenis } \\
\text { Kelamin }\end{array}$ & $\begin{array}{c}\text { Frekuensi } \\
(\mathrm{F})\end{array}$ & $\begin{array}{c}\text { Persentase } \\
(\%)\end{array}$ \\
\hline 1 & Laki-laki & 18 & 60 \\
2 & Perempuan & 12 & 40 \\
\hline & Jumlah & 30 & 100 \\
\hline
\end{tabular}

Berdasarkan tabel 1 didapatkan bahwa dari 30 responden sebagian besar (60\%) berjenis kelamin laki-laki.

Tabel 2 Distribusi frekuensi kepercayaan diri anak usia 3-5tahun sebelum diberikan alat permainan edukatif (pretest) di $\mathrm{KB}$ Aisyiyah 14 Pabean Cantian Kota Surabaya

\begin{tabular}{cccc}
\hline No & $\begin{array}{c}\text { Kepercayaan } \\
\text { Diri Anak } \\
(\text { Pretest })\end{array}$ & $\begin{array}{c}\text { Frekuensi } \\
(\mathrm{F})\end{array}$ & $\begin{array}{c}\text { Persentase } \\
(\%)\end{array}$ \\
\hline 1 & Tinggi & 3 & 10 \\
2 & Sedang & 6 & 20 \\
\hline
\end{tabular}




\begin{tabular}{cccc}
\hline 3 & Kurang & 21 & 70 \\
\hline & Jumlah & 30 & 100 \\
\hline
\end{tabular}

Berdasarkan tabel 2 menunjukkan sebagian besar (70\%) mempunyai kepercayaan diri rendah.

Tabel 3 Distribusi frekuensi kepercayaan diri anak usia 3-5 tahun sesudah diberikan alat permainan edukatif (posttest) di $\mathrm{KB}$ Aisyiyah 14 Pabean Cantian Kota Surabaya

\begin{tabular}{cccc}
\hline No & $\begin{array}{c}\text { Kepercayaan } \\
\text { Diril Anak } \\
(\text { Posttest })\end{array}$ & $\begin{array}{c}\text { Frekuensi } \\
(\mathrm{F})\end{array}$ & $\begin{array}{c}\text { Persentase } \\
(\%)\end{array}$ \\
\hline 1 & Tinggi & 19 & 63,33 \\
2 & Sedang & 9 & 30 \\
3 & Kurang & 2 & 6,67 \\
\hline & Jumlah & 30 & 100 \\
\hline
\end{tabular}

Berdasarkan tabel 3 menunjukkan sebagian besar $(63,33 \%)$ mempunyai kepercayaan diri tinggi.

Tabel 4 Pengaruh penerapan alat permainan edukatif terhadap peningkatan kepercayaan diri anak usia 3-5 tahun di KB Aisyiyah 14 Pabean Cantian Kota Surabaya

\begin{tabular}{llllllllll}
\hline \multirow{2}{*}{$\begin{array}{c}\text { Penerapan } \\
\text { Alat }\end{array}$} & \multicolumn{4}{c}{ Kepercayaan Diri Anak } & \multicolumn{2}{c}{ Total } \\
\cline { 2 - 9 } $\begin{array}{c}\text { Permainan } \\
\text { Edukatif }\end{array}$ & $\mathrm{n}$ & $\%$ & $\mathrm{n}$ & $\%$ & $\mathrm{n}$ & $\%$ & $\mathrm{n}$ & $\%$ \\
\hline Pre Test & 3 & 10 & 6 & 20 & 21 & 70 & 30 & 100 \\
Post Test & 19 & 63,3 & 9 & 30 & 2 & 6,7 & 30 & 100 \\
\hline Wilcoxon Sign Rank Test $\rho=0.000$ & & & & & & & & & \\
\hline
\end{tabular}

Berdasarkan tabel 4 dari 30 responden sebelum diberikan penerapan alat permainan edukatif didapatkan sebagian besar (70\%) responden memiliki kepercayaan diri rendah, sebagian kecil (20\%) memiliki kepercayaan diri sedang dan sebagian kecil (10\%) memiliki kepercayaan diri tinggi dan setelah diberikan penerapan alat permainan edukatif didapatkan dari 30 responden sebagian besar $(63,33 \%)$ mempunyai kepercayaan diri tinggi, hampir setengahnya (30\%) memiliki kepercayaan diri sedang dan sebagian kecil $(6,67 \%)$ memiliki kepercayaan diri rendah.

Berdasarkan hasil uji statistik dengan menggunakan uji Wilcoxon Sign Rank Test sebelum dan sesudah diberikan penerapan Alat Permainan Edukatif (APE) didapatkan nilai kemaknaan $\rho=0,000$ dimana $\rho<0,05$ yang berarti Ho ditolak yang artinya ada pengaruh penerapan Alat Permainan Edukatif (APE) terhadap peningkatan kepercayaan diri anak usia 3-5 tahun di KB Aisyiyah 14 Pabean Cantian Kota Surabaya.

Berdasarkan tabel 4 dari total 30 responden sebelum diberikan penerapan Alat Permainan Edukatif didapatkan data sebagian besar $(70 \%)$ responden memiliki kepercayaan diri rendah, sebagian kecil (20\%) memiliki kepercayaan diri sedang dan sebagian kecil (10\%) memiliki kepercayaan diri tinggi. Kemudian setelah diberikan penerapan Alat Permainan Edukatif didapatkan data dari total 30 responden sebagian besar $(63,33 \%)$ mempunyai kepercayaan diri tinggi, hampir setengahnya (30\%) memiliki kepercayaan diri sedang dan sebagian kecil $(6,67 \%)$ memiliki kepercayaan diri rendah. 
Anak pada usia pra sekolah ini (3-5 tahun) sebenarnya memiliki potensi untuk membangun kepercayaan dalam dirinya, salah satunya dengan APE. Anak yang sudah diberikan penerapan APE sebagian besar sudah memiliki kepercayaan dirinya. Hal ini disebabkan melalui APE otak anak terangsang untuk berkembang sehingga perkembangan kepercayaan dirinyapun meningkat.

\section{PEMBAHASAN}

Kepercayaan Diri Anak Usia 3-5 Tahun Sebelum Dilakukan Penerapan Alat Permainan Edukatif (APE)

Berdasarkan tabel 2 menunjukkan dari total 30 responden 21 anak mempunyai kepercayaan diri yang kurang artinya kemampuan inisiatif, kreatif, optimis dan berfikir positif masih kurang sesuai dengan tahap perkembangannya. Kepercayaan diri kurang ini dapat disebabkan oleh faktorfaktor yang mempengaruhi kepercayaan diri anak. Menurut teori Ghufron (2012) yang mengemukakan bahwa jenis kelamin merupakan salah satu faktor yang mempengaruhi kepercayaan diri anak, dibuktikan berdasarkan tabel 1 didapatkan bahwa dari 30 responden 18 anak berjenis kelamin laki-laki, tetapi dari 21 anak yang memiliki tingkat kepercayaan diri kurang tersebut sebagian besar $11(52 \%)$ adalah anak perempuan anak. Hasil diatas didukung oleh teori dari Ghufron (2012) yang mengemukakan bahwa kepercayaan diri anak laki-laki lebih tinggi diabandingkan dengan perempuan. Misalkan anak perempuan selalu merasa dirinya lebih rendah daripada laki-laki seperti perasaan kurang mampu. Hal ini mungkin terjadi karena peran orang tua dan harapan-harapan masyarakat yang berbeda terhadap anak. Pada usia inilah anak harus diberikan rangsangan untuk mengembangkan kemampuan psikologis yaitu kepercayaan diri.

Bentuk kepercayaan diri yang kurang dari hasil penelitian ini antara lain sebagian anak belum bisa melakukan kegiatan yang menjadi salah satu unsur kepercayaan diri anak, yaitu anak belum berani tampil di depan kelas tanpa diminta, anak belum berani mengungkapkan pendapat, anak belum berani untuk menjawab pertanyaan, anak juga belum bisa memberitahu jika sudah menyelesaikan permainan dan belum bisa mengembalikan permainan ke tempat semula. Anak pada usia ini juga seharusnya bisa untuk mengemukakan pendapatnya

Kepercayaan Diri Anak Usia 3-5 Tahun Setelah Dilakukan Penerapan Alat Permainan Edukatif (APE)

Kepercayaan diri anak berdasarkan tabel 3 menunjukkan anak yang diberikan 
penerapan APE (Alat Permainan Edukatif) sebagian besar $(63,33 \%)$ mempunyai kepercayaan diri tinggi dan hampir setengahnya (30\%) memiliki kepercayaan diri sedang. Kepercayaan diri tinggi setelah penerapan APE didukung oleh hasil observasi penelitian antara lain: Pertama, sebelum dilakukan penerapan APE dari 30 total responden, 27 mampu berpisah dengan orang tua tanpa menangis, 24 anak mampu bermain tanpa dibantu orang tua dan 7 anak melakukan aktivitas tanpa dibantu. Tetapi setelah penerapan APE seluruh anak mampu berpisah dengan orang tua tanpa menangis, seluruh anak mampu bermain tanpa dibantu orang tua dan 27 anak melakukan aktivitas tanpa dibantu. Kondisi tersebut mencerminkan anak sudah mampu mandiri karena telah memiliki rasa percaya diri yang tinggi. Anak akan merasa berani untuk melakukan aktivitas tanpa merasa takut. Karena menurut Santrock (dalam Puspita, 2013) mengungkapkan bahwa masa kanak-kanak awal (prasekolah) termasuk ke dalam masa emas perkembangan. Selama masa prasekolah anak belajar untuk menjadi lebih mandiri, dan untuk menjadi seorang yang mandiri anak harus memiliki kepercayaan diri. Saat anak memiliki rasa percaya diri, anak akan mampu untuk melakukan aktivitas tanpa dibantu orang tua ataupun orang lain
Pengaruh Penerapan Alat Permainan Edukatif (APE) Terhadap Peningkatan Kepercayaan Diri Anak Usia 3-5 Tahun Hasil uji Wilcoxon Sign Rank Test didapatkan nilai kemaknaan $\rho=0,000$ dimana $\rho<0,05$ yang berarti Ho ditolak yang artinya ada pengaruh penerapan Alat Permainan Edukatif (APE) terhadap peningkatan kepercayaan diri anak.

Hasil diatas membuktikan bahwa dengan stimulasi APE, kepercayaan anak dapat meningkat. Otak anak 3 -5 tahun memiliki jutaan sel dan sinapsis yang terus berkembang dan perkembangan akan semakin baik bila dilakukan stimulasi. Otak anak akan tumbuh secara cepat dengan memproduksi jutaan sel, koneksi atau sinaps diantara sel-sel tersebut. Kepercayaan diri juga akan menumbuhkan aspek kepribadian dan tingkah laku anak. Anak akan semakin berani untuk mengungkapkan pendapatnya. Semakin anak berani untuk mengungkapkan pendapatnya, anak akan menjadi pribadi yang penuh percaya diri. Jadi, kepercayaan diri anak harus mulai dibangun sejak usia dini yaitu usia 3-5 tahun.

\section{SIMPULAN DAN SARAN}

\section{Simpulan}

Dari hasil analisis dan pembahasan yang telah dilakukan oleh peneliti maka dapat disimpulkan bahwa: 
1. Anak sebagian besar mempunyai kepercayaan diri rendah sebelum diberikan penerapan APE (Alat Permainan Edukatif) di KB Aisyiyah 14 Pabean Cantian Surabaya.

2. Anak sebagian besar mempunyai kepercayaan diri tinggi dan hampir setengahnya memiliki kepercayaan diri sedang sesudah diberikan penerapan APE (Alat Permainan Edukatif) di KB Aisyiyah 14 Pabean Cantian Surabaya.

3. Penerapan APE (Alat Permainan Edukatif) dapat meningkatkan kepercayaan diri anak.

\section{Saran}

1. Bagi peneliti selanjutnya

Perlu dikembangkan dan diadakan penelitian lebih lanjut yang dilihat dari faktor lain dengan harapan wawasan yang baru. Penelitian ini dapat menjadi pedoman pada penelitian selanjutnya diharapkan dapat menjadi kelompok kontrol dan pembanding dalam penelitian selanjutnya.

2. Bagi institusi pendidikan

Luangkan sedikit waktu untuk melakukan penerapan APE (Alat Permainan Edukatif) di dalam kelas karena penerapan APE (Alat Permainan Edukatif) salah satu cara untuk mengembangkan kepercayaan diri anak usia 3-5 tahun.

3. Bagi orang tua
Orang tua harusnya memfasilitasi anak dengan permainan edukatif dan mendampingi anak saat bermain karena stimulasi dari permainan serta perhatian khusus dari orang tua dapat meningkatkan hubungan sosial dan cara berinteraksi secara baik serta dapat meningkatkan kecerdasan dan kematangan cara berfikir otak anak.

4. Bagi profesi keperawatan Penerapan APE (Alat Permainan Edukatif) dapat menjadi salah satu asuhan keperawatan dalam mengembangkan kepercayaan diri anak.

\section{DAFTAR PUSTAKA}

Adriana, Dian. (2013). Tumbuh Kembang dan Terapi Bermain pada Anak. Jakarta: Salemba Medika

Ayu, Sinta. (2014). Hubungan Pengetahuan Orang Tua Tentang Alat Permainan Edukatif (APE) dengan Perkembangan Anak Prasekolah. www.akbidharapanmulya.ac.id. Diakses tanggal 16 Oktober 2016.

Dariyo, Agoes. (2011). Psikologi Perkembangan Anak Tiga Tahun Pertama. Jakarta: Salemba Medika

Ghufron, Nur dan Rini. (2012). TeoriTeori Psikologi. Jogjakarta: Ar-Ruzz Media

Hidayat, Alimul Aziz. 2005. Pengantar Ilmu Keperawatan Anak 1. Jakarta: Salemba Medika

Karnadi. (2012). Pengaruh Jenis Kelamin Dan Kreativitas TerhadapKemampuan Mengemukakan Pendapat Anak Kelas Rendah Di Sekolah Dasar. 
$w w w$.journal.unesa.ac.id. Diakses tanggal 1 Maret 2017

Kasim, Hasna. (2013). Meminimalkan Perilaku Pemalu Pada Anak Kelompok B Melalui Teknik Modeling Di Tk AlHidayah Kecamatan Telaga Kabupaten Gorontalo. www.kim.ung.ac.id. Diakses tanggal 1 Maret 2017.

Kyle, Terri \& Carman, Susan. 2015. Buku Praktik Keperawatan Pediatrik. Jakarta: EGC Medika

Mudlifatin, Erfa. (2012). Meningkatkan Kepercayaan Diri Anak Melalui MediaTabung Pintar Pada Kegiatan Menyusun Kata. www.ejournal. unesa.ac.id. Diakses tanggal 30 September 2016

Ngadilah. (2011). Pengaturan Penggunaan dan Penambahan Alat Permainan Edukatif. www. eprints.uny.ac.id. Diakses tanggal 11 Oktober 2016।

Nisa. (2015). Optimalisasi Metode Bermain Peran Dengan Menggunakan Alat Permainan Edukatif Dalam Mengasah Percaya Diri Anak Usia Dini. www.download. portalgaruda.org. Diakses tanggal 27 September 2016.

Notoatmodjo, Soekidjo. (2012). Metodologi Penelitian Kesehatan. Jakarta: Rineka Cipta.

Nursalam. (2005). Asuhan Keperawatan Bayi dan Anak (untuk Perawat dan Bidan). Jakarta: Salemba Medika

Nursalam. (2013). Konsep dan Penerapan Metodologi Penelitian Ilmu Keperawatan. Bandung: Alfabeta

Puspita, Ayu. (2013). Hubungan Pola Asuh Orang Tua Dengan Kepercayaan Diri Pada Anak Prasekolah (3-5 Tahun) Di Tk Iv Saraswati Denpasar Tahun 2012.
Rahayu, Aprianti. (2013). Menumbuhkan Kepercayaan Diri Melalui Kegiatan Bercerita. Jakarta: PT Indeks

Restu, Adhita. (2013). Meningkatkan Rasa Percaya Diri Anak Kelompok B Melalui Kegiatan Bermain Aktif. www.eprint.uny.ac.id. Diakses tanggal 30 September 2016

Setiadi. 2013. Konsep dan Praktik Penulisan Riset Keperawatan. "Edisi 2”. Yogyakarta: Graha Ilmu

Siddik, Fathir. (2015). Hubungan Penggunaan Alat Permainan Edukatif dengan Perkembangan Anak Usia 3-5 Tahun di Paud Uswatun Khasanah Saleman Yogyakarta. www.opac.unisayogya.ac.id. Diakses tanggal 20 Oktober 2016.

Siska. (2011). Meningkatkan Percaya Diri Melalui Permainan Out Bund Sederhana. www.ung.ac.id. Diakses tanggal 20 Oktober 2016

Sugiyono. 2011. Metode Penelitian Kuantitatif Kualitatif. Bandung: Penerbit Alfabeta

Supartini, Yupi. 2012. Buku Ajar Konsep Dasar Keperawatan Anak. Jakarta: EGC

Suriadi \& Yuliani, Rita. 2010. Asuhan Keperawatan pada Anak "Edisi 2". Jakarta: Cv Sagung Seto

Susilaningrum, Rekawati, Nursalam dan Sri Utami. (2013). Asuhan Keperawatan Bayi dan Anak. Jakarta: Salemba

www. ejournal.unsrat.ac.id. Diakses tanggal 1 Maret 2017

Yuniarti, Sri. 2015. Asuhan Tumbuh Kembang Neonatus Bayi - Balita dan Anak Pra Sekolah. Bandung: PT Refika Aditama 